\title{
Human Papillomavirus Prevalence and Distribution according to Age among Korean and Chinese Women
}

\author{
Geehyuk Kim ${ }^{1}$, Sunghyun Kim², Sunyoung Park ${ }^{1}$, Sangjung Park ${ }^{3}$, Han Lin $^{4}$, Yubo Ren ${ }^{4}$, Li Yingxue ${ }^{4}$, \\ In Soo Lee ${ }^{5}$, Jae Dal Lee ${ }^{5}$, and Dongsup Lee ${ }^{5}$
}

\footnotetext{
${ }^{1}$ Department of Biomedical Laboratory Science, College of Health Sciences, Yonsei University, Wonju, Gangwon, Korea

${ }^{2}$ Department of Clinical Laboratory Science, College of Health Sciences, Catholic University of Pusan, Pusan, Korea

${ }^{3}$ Department of Clinical Laboratory Science, College of Medical Science, Daegu Haany University, Daegu, Korea

${ }^{4}$ Department of Pathology, Liaocheng School of Clinical Medicine, Taishan Medical University, Liaocheng, Shandong, China

${ }^{5}$ Department of Clinical Laboratory Science, Hyejeon College, Hongseong, Chungnam, Korea
}

\section{중국과 한국여성에서 나이에 따른 인유두종바이러스의 유병률과 분포}

\author{
김지혁 ${ }^{1}$, 김성현 ${ }^{2}$, 박선영 ${ }^{1}$, 박상정 ${ }^{3},{\operatorname{Han~} \operatorname{Lin}^{4}, \text { Yubo } \operatorname{Ren}^{4}, \text { Li Yingxue }}^{4}$, 이인수 ${ }^{5}$, 이재달 ${ }^{5}$, 이동섭 ${ }^{5}$ \\ ${ }^{1}$ 연세대학교 임상병리학과, ${ }^{2}$ 부산카톨릭대학교 임상병리학과, ${ }^{3}$ 대구한의과대학 임상병리학과, ${ }^{4}$ 태산 랴오청 인민병원 병리과, ${ }^{5}$ 혜전대학교 임상병리과
}

\begin{abstract}
Cervical cancer is the third most common cancer among women worldwide. Cervical cancer is significantly associated with human papillomavirus (HPV) infection. The prevalence of HPV infection is influenced by geography, immune status, sexual history and genetic factors. For example, geographically, HPV prevalence varies from 1.5\% to 39\%. However, little is known about the relationship between HPV prevalence and age. An analysis of HPV prevalence by age will help determine when high-risk groups are exposed to HPV. Such an analysis could also demonstrate a correlation between specific HPV genotypes and age. In addition, the analysis might clarify the optimum age for using vaccines. In this study, HPV prevalence and genotype distribution among Korean and Chinese women are analyzed by age. The REBA HPV-ID ${ }^{\circledR}$ assay (YD diagnostics, Yong-in, Republic of Korea) was used for detecting HPV genotypes in uterine cervical liquid-based cytology samples from 533 women from Korea and 324 from East China (Western Shandong province. Women with severe dysplasia such as SCC (Squamous cell carcinoma) and HSIL (High-grade squamous intraepithelial lesion) groups were primarily in their 40 s and 50s, whereas women with mild and moderate dysplasia (ASCUS and LSIL groups) were primarily in their 30s and 40s. Women with HPV genotype 16 and 18 infections were primarily in their 40s. The results suggest that HPV infection is associated with certain age groups in the Korean population.
\end{abstract}

Keywords: Human papillomavirus, DNA genotyping, China, Korea, Age

This is an Open Access article distributed under the terms of the Creative Commons Attribution Non-Commercial License (http://creativecommons.org/licenses/by-nc/4.0) which permits unrestricted non-commercial use, distribution, and reproduction in any medium, provided the original work is properly cited.

Copyright @ 2015 The Korean Society for Clinical Laboratory Science. All rights reserved.
Corresponding author: Dongsup Lee Department of Clinical Laboratory Science, Hyejeon College, Chungnam 350-702, Korea Tel: 82-41-630-5342

E-mail: eastern3547@naver.com

Received: October 8, 2015

Revised: November 9, 2015

Accepted: November 9, 2015

\section{Introduction}

Cervical cancer is the third most common cancer in women worldwide. The occurrence of cervical cancer is estimated at 493,000 women every year, and mortality rates have decreased (Jemal et al., 2011). Globally, approximately 274,000 women die every year (Jennifer, 2013).

Cervical cancer is significantly associated with human 
papillomavirus (HPV) infection. Persistent HPV infections are the primary cause of cervical cancer (zur Hausen, 1994; Munoz et al., 2003). In addition, HPV is an etiologic agent for dysplasia. After HPV infection, E6 and E7 viral proteins act as an oncogene by disrupting the activity of p53 and pRB, respectively (Jennifer, 2013; Andersson et al., 2011). These proteins are also responsible for the transformation of epithelial cells and maintenance of malignancy. HPV DNA has been detected in most cervical squamous cell carcinomas (SCCs) and a small portion of adenocarcinomas (Bosch et al., 1995; Bosch \& Munoz, 2002). There are currently 13 high-risk HPV types classified as Group 1 carcinogens (i.e., highly carcinogenic to humans) (HPV 16, 18, 31, 33, 35, 39, 45, 51, 52, 56, 58, 59 and 68) and Group 2A carcinogens (i.e., probably carcinogenic) (HPV 26, 30, 34, 53, 66, 67, 69, 70, 73, 82, 85 and 97) (IARC, 2012) (Bouvard et al., 2009). Molecular diagnosis makes the best use of a high risk of HPV into a cervical cancer diagnosis.

Studies about the prevalence of HPV infections vary widely. Prevalence is influenced by geography, age, immune status, sexual history and genetic factors (Jennifer et al., 2013). Sub-Saharan Africa, Latin America and the Caribbean, Eastern Europe, and Southeastern Asia have the highest prevalence of HPV infections (Bruni et al., 2010). Prevalence rates vary from $1.5 \%$ in Spain to 39\% in Honduras and Kenya. However, little is known about the relationship between HPV prevalence and age. An analysis of HPV prevalence by age will help determine when high-risk groups are exposed to cervical cancer. Such an analysis could also demonstrate a correlation between specific HPV genotypes and age. In addition, the analysis might clarify the optimum age for injecting vaccine.

In this study, REBA HPV-ID ${ }^{\circledR}$ assay (YD diagnostics, Yong-in, Republic of Korea), which is a reverse blot hybridization-based assay (REBA) that employs probes for 15 high-risk (HR)-HPV genotypes (HPV 16, 18, 31, 33, 35, 39, 45, $51,52,53,56,58,59,66$, and 68) and 10 low-risk (LR)-HPV genotypes (HPV 6, 11, 42, 43, 44, 70, 72, 81, 84, and 87), was used from a total of 533 Korean women and 324 East Chinese women. Subsequently, HPV prevalence and genotype distribution in Korean and Chinese women are analyzed by age.

\section{Materials and Methods}

\section{Patients and clinical samples}

Between January 2013 and December 2013, liquid-based cytology samples were collected from 324 women who visited the Liaocheng People's Hospital in the Shandong province of China. This study was approved by the Institutional Ethics Committee of Yonsei University Wonju College of Medicine (approval no. 2011-0038) and all subjects provided written informed consent. Average age was 43.4 years (SD 12.4 years, range 21 79 years). Between March 2012 and February 2014, liquid-based cytology samples were collected from 533 women who attended Yonsei University Wonju Severance Christian Hospital in Wonju, Korea. All clinical samples were collected using ThinPrep ${ }^{\mathbb{R}}$ (Hologic Inc., Bedford, MA, USA) materials. Average age was 47.3 years (SD 12.5 years, range 17 90 years).

\section{Cytological diagnosis}

Liquid-based cytology slides (Pap smears) were evaluated according to the 2001 Bethesda System by cytopathologists and pathologists. Cases with normal (within normal limit, reactive change due to inflammation, fungal infection, and atrophy), atypical squamous cells of undetermined significance (ASC-US), atypical squamous cells - cannot exclude HSIL (ASC-H), low-grade squamous intraepithelial lesion (LSIL), HSIL, and squamous cell carcinoma (SCC) cytological results were included. The remaining fluid samples were stored at $4^{\circ} \mathrm{C}$ after cytology slide preparation, but before DNA extraction.

\section{DNA extraction}

DNA extraction was performed using the HPV DNA Extraction Solution (M\&D, Wonju, Republic of Korea), according to the manufacturer's recommendations. Briefly, remaining clinical samples were collected in 50-mL tubes and vortexed for about $1 \mathrm{~min}$. The volume was adjusted to $40 \mathrm{ml}$ with PBS $(\mathrm{pH} 7.2)$ and centrifuged at $2,000 \times g$ at $4^{\circ} \mathrm{C}$ for $30 \mathrm{~min}$. The supernatant was discarded and 300 $500 \mu \mathrm{L}$ of sterile distilled water (DW) was added to the pellet, vortexed, transferred to a 1.5-mL Eppendorf tube, and then centrifuged at 17,590 $\times g$ at $4^{\circ} \mathrm{C}$ for $5 \mathrm{~min}$. The supernatant was discarded. DNA 
extraction solution $(100 \mu \mathrm{L})$ was added to the pellet, vortexed for $1 \mathrm{~min}$, and incubated at $56^{\circ} \mathrm{C}$ for $15 \mathrm{~min}$ with intermittent tube tapping. After incubation, samples were boiled in water for $10 \mathrm{~min}$ and centrifuged at $17,590 \times \mathrm{g}$ for $3 \min \left(25^{\circ} \mathrm{C}\right.$ ), and then the supernatant ( 3 to $5 \mu \mathrm{L}$ ) was used as a template for PCR.

\section{HPV genotyping}

HPV genotyping was performed using the REBA HPV-ID ${ }^{\circledR}$ kit (M\&D, Wonju, Republic of Korea), according to the manufacturer's recommendations. This genotyping method required nested PCR to amplify the target regions including MY11 and MY9, and GP5 and GP6, with two primer pairs. Nested PCR conditions consisted of an initial denaturation step for $5 \mathrm{~min}$ at $94^{\circ} \mathrm{C}, 15$ cycles of denaturation for $30 \mathrm{sec}$ at $94^{\circ} \mathrm{C}$, and extension for $30 \mathrm{sec}$ at $65^{\circ} \mathrm{C}$. The subsequent 45 cycles were $30 \mathrm{sec}$ at $94^{\circ} \mathrm{C}$, and $30 \mathrm{sec}$ at $54^{\circ} \mathrm{C}$. The final extension step was performed at $72^{\circ} \mathrm{C}$ for $7 \mathrm{~min}$. After PCR amplification, the following steps were performed according to the manufacturers' instructions. PCR products were added to the HPV genotype-specific probe-labeled membrane strip, leftover PCR products were washed, and then the colorimetric signals from the hybridized PCR products were generated and observed.

\section{Results}

\section{Cytological diagnosis among China and Korea}

Liquid-based cytology slides (Pap smears) were evaluated according to the 2001 Bethesda System. Five hundred and thirty-three sample specimens from Korean women were classified into six categories by cytological criteria: 191 (35.8\%) normal, 100 (18.8\%) ASC-US, 101 (18.9\%) LSIL, 24
(4.5\%) ASC-H, 72 (13.5\%) HSIL, and 45 (8.4\%) SCC (Table 1). Three hundred and twenty-four sample specimens from Chinese women were classified into six categories by cytological criteria: 79 (24.4\%) normal, 96 (29.6\%) ASC-US, 59 (18.2\%) LSIL, 19 (5.9\%) ASC-H, 67 (20.7\%) HSIL, and 4 (1.2\%) SCC (Table 1). In total, eight hundred and fifty-seven sample specimens were classified into six categories by cytological criteria: 270 (31.5\%) normal, 196 (22.9\%) ASC-US, 160 (18.7\%) LSIL, 43 (5.0\%) ASC-H, 139 (16.2\%) HSIL, and 49 (5.7\%) SCC (Table 1).

\section{Cytological diagnosis based on age}

Subjects were classified into five categories by age: $<30$ years old, 30 39 years old, 40 49 years old, 50 59 years old and $\geq 60$ years old (Table 2). Korean women who were $<30$ years old, 30 39 years old, 40 49 years old, 50 59 years old and $\geq 60$ years old accounted for 19 (3.6\%), 105 (19.7\%), 193 (36.2\%), 141 (26.5\%) and 75 (14.1\%), respectively (Table 2). Chinese women who were $<30$ years old, $30 \sim 39$ years old, 40 49 years old, 50 59 years old and $\geq 60$ years old accounted for 50 (15.4\%), 64 (19.8\%), 97 (29.9), 77 (23.8\%) and $36(11.1 \%)$, respectively (Table 2). Of the 45 SCC cytological samples from Korean women, $3(0.6 \%)$ cases were 30 39 years old, $12(2.3 \%)$ cases were $40 \sim 49$ years old, 11 (2.1\%) cases were 50 59 years old, $19(3.6 \%)$ cases were $\geq 60$ years old. Of the 4 squamous cell carcinoma (SCC) cytologic samples from Chinese women, $3(0.9 \%)$ cases were 50 59 years old and $1(0.3 \%)$ case was $\geq 60$ years old.

\section{HPV infection patterns according to age}

HPV infection patterns were classified as a single infection, multiple infections, other type of infection, or negative. Single and multiple infections were then classified as high-risk HPV

Table 1. Cytological diagnosis among Chinese and Korean women

\begin{tabular}{crrrrrrr}
\hline \multirow{2}{*}{ Ethnicity } & \multicolumn{9}{c}{ Cytological diagnosis } & Total \\
\cline { 2 - 6 } & Normaln (\%) & ASC-USn (\%) & L-SILn (\%) & ASC-Hn (\%) & H-SILn (\%) & SCCn (\%) & n (\%) \\
\hline Korean & $191(35.8)$ & $100(18.8)$ & $101(18.9)$ & $24(4.5)$ & $72(13.5)$ & $45(8.4)$ & $533(100)$ \\
Chinese & $79(24.4)$ & $96(29.6)$ & $59(18.2)$ & $19(5.9)$ & $67(20.7)$ & $4(1.2)$ & $324(100)$ \\
\hline
\end{tabular}

Abbreviation: ASC-US, atypical squamous cells of undetermined significance; LSIL, low grade squamous intraepithelial lesion; ASC-H, atypical squamous cells -cannot exclude HSIL; HSIL, high grade squamous intraepithelial lesion; SCC, squamous cell carcinoma. 
infection or low-risk HPV infection (Table 3). In Korean women, 250 cases (46.9\%) were infected with a single HPV genotype, 63 cases $(11.8 \%)$ were infected with multiple HPV genotypes (infected with more than two HPV genotypes), 63 cases $(11.8 \%)$ were infected with other HPV genotypes, and 157 cases (29.5\%) were HPV negative. Of the 250 single HPV genotype infection cases, 240 cases (45.0\%) were infected with HR-HPV genotypes and 10 cases (1.9\%) were infected with LR-HPV genotypes. Of the 63 multiple HPV genotype infection cases, 61 cases (11.4\%) were infected with HR-HPV genotypes and 2 cases $(0.4 \%)$ were infected with both HRand LR-HPV genotypes (HR- and LR-HPV genotype mixed

Table 2. Cytological diagnosis by age

\begin{tabular}{|c|c|c|c|c|c|c|c|}
\hline \multirow{2}{*}{ Ethnicity } & \multirow{2}{*}{ Cytological diagnosis } & \multicolumn{5}{|c|}{ Age group } & \multirow{2}{*}{$\begin{array}{l}\text { Total } \\
\text { n (\%) }\end{array}$} \\
\hline & & $<30$ n (\%) & $30 \sim 39$ n (\%) & $40 \sim 49$ n (\%) & $50 \sim 59$ n (\%) & $\geq 60$ n (\%) & \\
\hline \multirow[t]{6}{*}{ Korean $(n=533)$} & SCC & $0(0)$ & $3(0.6)$ & $12(2.3)$ & $11(2.1)$ & $19(3.6)$ & $45(8.4)$ \\
\hline & HSIL & $2(0.4)$ & $19(3.6)$ & $21(3.9)$ & $18(3.4)$ & $12(2.3)$ & $72(13.5)$ \\
\hline & ASC-H & $1(0.2)$ & $5(0.9)$ & $6(1.1)$ & $5(0.9)$ & $7(1.3)$ & $24(4.5)$ \\
\hline & LSIL & $3(0.6)$ & $11(2.1)$ & $30(5.3)$ & $42(7.9)$ & $15(2.8)$ & $101(18.9)$ \\
\hline & ASC-US & $7(1.3)$ & $23(4.3)$ & $31(5.8)$ & $25(4.7)$ & $14(2.6)$ & $100(18.8)$ \\
\hline & normal & $6(1.1)$ & $44(8.3)$ & $93(17.4)$ & $40(7.5)$ & $8(1.5)$ & $191(35.8)$ \\
\hline \multirow[t]{6}{*}{ Chinese $(n=324)$} & SCC & $0(0)$ & $0(0)$ & $0(0)$ & $3(0.9)$ & $1(0.3)$ & $4(1.2)$ \\
\hline & HSIL & $8(2.5)$ & $13(6.3)$ & $24(7.4)$ & $16(4.9)$ & $6(1.9)$ & $67(20.7)$ \\
\hline & ASC-H & $1(0.3)$ & $3(0.9)$ & $8(2.5)$ & $6(1.9)$ & $1(0.3)$ & $19(5.9)$ \\
\hline & LSIL & $16(4.9)$ & $16(4.9)$ & $14(4.3)$ & $8(2.5)$ & $5(1.5)$ & $59(18.2)$ \\
\hline & ASC-US & $10(3.1)$ & $15(4.6)$ & $28(8.6)$ & $27(8.3)$ & $16(4.9)$ & $96(29.6)$ \\
\hline & normal & $15(4.6)$ & $17(5.2)$ & $23(7.1)$ & $17(5.2)$ & $7(2.2)$ & $79(24.4)$ \\
\hline
\end{tabular}

Table 3. HPV infection patterns according to age

\begin{tabular}{|c|c|c|c|c|c|c|}
\hline \multirow{2}{*}{$\begin{array}{l}\text { Infection Patterns } \\
\text { in Korean women }\end{array}$} & \multicolumn{6}{|c|}{ Age groups } \\
\hline & $\begin{array}{c}<30 \\
\mathrm{n}=19(\%)\end{array}$ & $\begin{array}{c}30 \sim 39 \\
n=105(\%)\end{array}$ & $\begin{array}{c}40 \sim 49 \\
n=193(\%)\end{array}$ & $\begin{array}{c}50 \sim 59 \\
n=141(\%)\end{array}$ & $\begin{array}{c}>60 \\
n=75(\%)\end{array}$ & $\begin{array}{c}\text { Total } \\
n=533(\%)\end{array}$ \\
\hline Single infection & $8(42.1)$ & $48(45.7)$ & $83(43.0)$ & 69 (48.9) & $41(54.7)$ & $250(46.9)$ \\
\hline HR infection & $6(31.6)$ & $47(44.8)$ & $79(40.9)$ & $66(46.8)$ & $40(53.3)$ & $240(45.0)$ \\
\hline LR infection & $2(10.5)$ & $1(1.0)$ & $4(2.1)$ & $3(2.1)$ & $1(1.3)$ & $10(1.9)$ \\
\hline Multiple infections & $4(21.1)$ & $12(11.4)$ & $23(11.9)$ & $13(9.2)$ & $12(16.0)$ & $63(11.8)$ \\
\hline HR infection & $3(15.8)$ & $12(11.4)$ & $23(11.9)$ & $12(8.5)$ & $11(14.7)$ & $61(11.4)$ \\
\hline LR infection & $0(0)$ & $0(0)$ & $0(0)$ & $0(0)$ & $0(0)$ & $0(0)$ \\
\hline$H R$ \& LR infection & $1(5.3)$ & $0(0)$ & $0(0)$ & $1(0.7)$ & $1(1.3)$ & $2(0.4,0.4)$ \\
\hline Other types of infection & $3(15.8)$ & $9(8.6)$ & $20(10.4)$ & $23(16.3)$ & $8(10.7)$ & $63(11.8)$ \\
\hline Negative & $4(23.5)$ & $36(34.4)$ & $67(34.7)$ & $36(25.5)$ & $14(18.7)$ & $157(29.5)$ \\
\hline \multirow{2}{*}{$\begin{array}{l}\text { Infection Patterns } \\
\text { in Chinese women }\end{array}$} & \multicolumn{6}{|c|}{ Age groups } \\
\hline & $\begin{array}{c}<30 \\
n=50(\%)\end{array}$ & $\begin{array}{c}30 \sim 39 \\
n=64(\%)\end{array}$ & $\begin{array}{c}40 \sim 49 \\
n=97(\%)\end{array}$ & $\begin{array}{c}50 \sim 59 \\
n=77(\%)\end{array}$ & $\begin{array}{c}>60 \\
n=36(\%)\end{array}$ & $\begin{array}{c}\text { Total } \\
n=324(\%)\end{array}$ \\
\hline Single infection & $21(42.0)$ & $28(43.8)$ & $40(41.2)$ & $33(42.9)$ & $13(36.1)$ & $135(41.7)$ \\
\hline HR infection & $19(38.0)$ & $26(40.6)$ & $40(41.2)$ & $31(40.3)$ & $12(33.3)$ & $128(39.5)$ \\
\hline LR infection & $2(4.0)$ & $2(3.1)$ & $0(0)$ & $2(2.6)$ & $1(2.8)$ & $7(2.2)$ \\
\hline Multiple infections & $6(12.0)$ & $8(12.5)$ & $12(12.4)$ & $5(6.5)$ & $2(5.6)$ & $33(10.2)$ \\
\hline HR infection & $4(8.0)$ & $5(7.8)$ & $6(6.2)$ & $5(6.5)$ & $0(0)$ & $20(6.2)$ \\
\hline LR infection & $0(0)$ & $0(0)$ & $0(0)$ & $0(0)$ & $0(0)$ & $0(0)$ \\
\hline HR \& LR infection & $2(4.0)$ & $3(4.7)$ & $6(6.2)$ & $0(0)$ & $2(5.6)$ & $13(4.0)$ \\
\hline Other types of infection & $11(22.0)$ & $21(32.8)$ & $26(26.8)$ & $22(28.6)$ & $11(30.6)$ & $91(28.1)$ \\
\hline Negative & $12(24.0)$ & $7(10.9)$ & $19(19.6)$ & $17(22.1)$ & $10(27.8)$ & $65(20.1)$ \\
\hline
\end{tabular}

Abbreviation: HR, high-risk; LR, low-risk. 
Table 4. HPV genotype distribution according to age

\begin{tabular}{|c|c|c|c|c|c|c|c|}
\hline \multirow{2}{*}{$\begin{array}{l}\text { Infection Patterns } \\
\text { in Korean women }\end{array}$} & \multirow{2}{*}{$\begin{array}{c}\text { HPV } \\
\text { genotype }\end{array}$} & \multicolumn{5}{|c|}{ Age } & \multirow{2}{*}{ Total } \\
\hline & & $>30(\%)$ & $30 \sim 39$ (\%) & $40 \sim 49(\%)$ & $50 \sim 59(\%)$ & $\geq 60$ (\%) & \\
\hline \multirow[t]{16}{*}{ High-risk } & HPV 16 & $3(13.0)$ & $24(20.0)$ & $43(19.3)$ & 29 (18.8) & $20(22.0)$ & 119 (19.5) \\
\hline & HPV 18 & $2(8.7)$ & $12(10.0)$ & $16(7.2)$ & $10(6.5)$ & $13(14.3)$ & $53(8.7)$ \\
\hline & HPV 31 & $0(0)$ & $3(2.5)$ & $4(1.8)$ & $1(0.6)$ & $2(2.2)$ & $10(1.6)$ \\
\hline & HPV 33 & $1(4.3)$ & $6(5.0)$ & $10(4.5)$ & $9(5.8)$ & $8(8.8)$ & $34(5.6)$ \\
\hline & HPV 35 & $0(0)$ & $0(0)$ & $5(2.2)$ & $7(4.5)$ & $4(4.4)$ & $16(2.6)$ \\
\hline & HPV 39 & $1(4.3)$ & $2(1.7)$ & $2(0.9)$ & $6(3.9)$ & $1(1.1)$ & $12(2.0)$ \\
\hline & HPV 45 & $0(0)$ & $0(0)$ & $1(0.4)$ & $2(1.3)$ & $0(0)$ & $3(0.5)$ \\
\hline & HPV 51 & $1(4.3)$ & $1(0.8)$ & $2(0.9)$ & $0(0)$ & $0(0)$ & $4(0.7)$ \\
\hline & HPV 52 & $1(4.3)$ & $8(6.7)$ & $3(1.3)$ & $4(2.6)$ & $1(1.1)$ & $17(2.8)$ \\
\hline & HPV 53 & $0(0)$ & $0(0)$ & $1(0.4)$ & $0(0)$ & $0(0)$ & $1(0.2)$ \\
\hline & HPV 56 & $0(0)$ & $4(3.3)$ & $6(2.7)$ & $5(3.2)$ & $1(1.1)$ & $16(2.6)$ \\
\hline & HPV 58 & $2(8.7)$ & $7(5.8)$ & $12(5.4)$ & $9(5.8)$ & $14(15.4)$ & $44(7.2)$ \\
\hline & HPV 59 & $1(4.3)$ & $0(0)$ & $1(0.4)$ & $2(1.3)$ & $0(0)$ & $4(0.7)$ \\
\hline & HPV 66 & $0(0)$ & $5(4.2)$ & $8(3.6)$ & $1(0.6)$ & $1(1.1)$ & $15(2.5)$ \\
\hline & HPV 68 & $1(4.3)$ & $3(2.5)$ & $12(5.4)$ & $6(3.9)$ & $2(2.2)$ & $24(3.9)$ \\
\hline & HPV 69 & $0(0)$ & $0(0)$ & $5(2.2)$ & $0(0)$ & $0(0)$ & $5(0.8)$ \\
\hline \multirow[t]{7}{*}{ Low-risk } & HPV 11 & $2(8.7)$ & $0(0)$ & $0(0)$ & $0(0)$ & $0(0)$ & $2(0.3)$ \\
\hline & HPV 40 & $1(4.3)$ & $0(0)$ & $1(0.4)$ & $1(0.6)$ & $0(0)$ & $3(0.5)$ \\
\hline & HPV 42 & $0(0)$ & $0(0)$ & $1(0.4)$ & $1(0.6)$ & $1(1.1)$ & $3(0.5)$ \\
\hline & HPV 43 & $0(0)$ & $0(0)$ & $0(0)$ & $1(0.6)$ & $0(0)$ & $1(0.2)$ \\
\hline & HPV 54 & $0(0)$ & $0(0)$ & $1(0.4)$ & $0(0)$ & $0(0)$ & $1(0.2)$ \\
\hline & HPV 70 & $0(0)$ & $0(0)$ & $1(0.4)$ & $1(0.6)$ & $1(1.1)$ & $3(0.5)$ \\
\hline & HPV 84 & $0(0)$ & $0(0)$ & $1(0.4)$ & $0(0)$ & $0(0)$ & $1(0.2)$ \\
\hline \multicolumn{2}{|c|}{ Other types of infection } & $3(13.0)$ & $9(7.5)$ & $20(9.0)$ & $23(14.9)$ & $8(8.8)$ & $63(10.3)$ \\
\hline \multicolumn{2}{|c|}{ Negative } & $4(17.4)$ & $36(30.0)$ & $67(30.0)$ & $36(23.4)$ & $14(15.4)$ & $157(25.7)$ \\
\hline \multicolumn{2}{|l|}{ Total } & $23(100)$ & $120(100)$ & $223(100)$ & $154(100)$ & $91(100)$ & $611(100)$ \\
\hline \multirow{2}{*}{$\begin{array}{l}\text { Infection Patterns } \\
\text { in Chinese women }\end{array}$} & \multirow{2}{*}{$\begin{array}{c}\text { HPV } \\
\text { genotype }\end{array}$} & \multicolumn{5}{|c|}{ Age } & \multirow{2}{*}{ Total } \\
\hline & & $<30(\%)$ & $30 \sim 39$ (\%) & 40 49 (\%) & $50 \sim 59(\%)$ & $\geq 60(\%)$ & \\
\hline \multirow[t]{15}{*}{ High-risk } & HPV 16 & $11(19.6)$ & $14(19.2)$ & $27(24.5)$ & $18(21.2)$ & $5(13.2)$ & $75(20.7)$ \\
\hline & HPV 18 & $3(5.4)$ & $4(5.5)$ & $5(4.5)$ & $6(7.1)$ & $0(0)$ & $18(5.0)$ \\
\hline & HPV 31 & $0(0)$ & $0(0)$ & $1(0.9)$ & $0(0)$ & $0(0)$ & $1(0.3)$ \\
\hline & HPV 33 & $2(3.6)$ & $2(2.7)$ & $6(5.5)$ & $2(2.4)$ & $2(5.3)$ & $14(3.9)$ \\
\hline & HPV 35 & $1(1.8)$ & $2(2.7)$ & $4(3.6)$ & $1(1.2)$ & $0(0)$ & $8(2.2)$ \\
\hline & HPV 39 & $0(0)$ & $0(0)$ & $2(1.8)$ & $1(1.2)$ & $1(2.6)$ & $4(1.1)$ \\
\hline & HPV 45 & $1(1.8)$ & $1(1.4)$ & $0(0)$ & $1(1.2)$ & $0(0)$ & $3(0.8)$ \\
\hline & HPV 51 & $0(0)$ & $2(2.7)$ & $0(0)$ & $0(0)$ & $0(0)$ & $2(0.6)$ \\
\hline & HPV 52 & $0(0)$ & $1(1.4)$ & $3(2.7)$ & $0(0)$ & $2(5.3)$ & $6(1.7)$ \\
\hline & HPV 53 & $3(5.4)$ & $3(4.1)$ & $4(3.6)$ & $8(9.4)$ & $2(5.3)$ & $20(5.5)$ \\
\hline & HPV 56 & $1(1.8)$ & $4(5.5)$ & $0(0)$ & $0(0)$ & $1(2.6)$ & $6(1.7)$ \\
\hline & HPV 58 & $3(5.4)$ & $3(4.1)$ & $5(4.5)$ & $4(4.7)$ & $0(0)$ & $15(4.1)$ \\
\hline & HPV 66 & $3(5.4)$ & $2(2.7)$ & $1(0.9)$ & $3(3.5)$ & $1(2.6)$ & $10(2.8)$ \\
\hline & HPV 69 & $1(1.8)$ & $1(1.4)$ & $0(0)$ & $0(0)$ & $0(0)$ & $2(0.6)$ \\
\hline & HPV 73 & $0(0)$ & $1(1.4)$ & $1(0.9)$ & $0(0)$ & $0(0)$ & $2(0.6)$ \\
\hline \multirow[t]{6}{*}{ Low-risk } & HPV 6 & $0(0)$ & $0(0)$ & $1(0.9)$ & $0(0)$ & $1(2.6)$ & $2(0.6)$ \\
\hline & HPV 11 & $1(1.8)$ & $1(1.4)$ & $3(2.7)$ & $0(0)$ & $0(0)$ & $5(1.4)$ \\
\hline & HPV 40 & $1(1.8)$ & $0(0)$ & $1(0.9)$ & $0(0)$ & $0(0)$ & $2(0.6)$ \\
\hline & HPV 43 & $0(0)$ & $0(0)$ & $0(0)$ & $1(1.2)$ & $0(0)$ & $1(0.3)$ \\
\hline & HPV 54 & $1(1.8)$ & $4(5.5)$ & $1(0.9)$ & $1(1.2)$ & $2(5.3)$ & $9(2.5)$ \\
\hline & HPV 84 & $1(1.8)$ & $0(0)$ & $0(0)$ & $0(0)$ & $0(0)$ & $1(0.3)$ \\
\hline \multicolumn{2}{|c|}{ Other types of infection } & $11(19.6)$ & $21(28.8)$ & $26(23.6)$ & $22(25.9)$ & $11(28.9)$ & $91(25.1)$ \\
\hline \multicolumn{2}{|c|}{ Negative } & $12(21.4)$ & $7(9.6)$ & $19(17.3)$ & $17(20.0)$ & $10(26.3)$ & $65(18.0)$ \\
\hline \multicolumn{2}{|l|}{ Total } & $56(100)$ & $73(100)$ & $110(100)$ & $85(100)$ & $38(100)$ & $362(100)$ \\
\hline
\end{tabular}


infection). In Chinese women, 135 cases (41.7\%) were infected with a single HPV genotype, 33 cases (10.2\%) were infected with multiple HPV genotypes (infected with more than two HPV genotypes), 91 cases (28.1\%) were infected with other HPV genotypes, and 65 cases (20.1\%) were HPV negative. Among the 135 cases with a single HPV genotype infection, 128 cases $(39.5 \%)$ were infected with HR-HPV genotypes and 7 cases $(2.2 \%)$ were infected with LR-HPV genotypes. Among 33 cases of multiple HPV genotype infection, 20 cases $(6.2 \%)$ were infected with HR-HPV genotypes and 13 cases (4.0\%) were infected with both HRand LR-HPV genotypes (HR- and LR-HPV genotype mixed infection) (Table 3).

\section{HPV genotype distribution according to age}

HPV genotypes 16, 18, 31, 33, 35, 39, 45, 51, 52, 53, 56, 58, $59,66,68$, and 69 were detected in Korean women, and the most prevalent HPV genotypes were 16 (19.5\%), 18 (8.7\%), 58 (7.2\%), 33 (5.6\%), 68 (3.9\%) in that order. HPV genotypes 16 and 18 were most prevalent in 40 49-year-olds. HPV genotypes 16, 18, 31, 33, 35, 39, 45, 51, 52, 53, 56, 58, 66, 69, and 73 were detected in Chinese women, and the most prevalent HPV genotypes were $16(20.7 \%), 53(5.5 \%), 18(5 \%)$, 58 (4.1\%), 33 (3.9\%), in that order. HPV genotypes 16 and 53 were most prevalent in 40 49-year-olds and 50 59 year olds, respectively (Table 4).

\section{Discussion}

Human papillomavirus (HPV) is closely associated with the development of cervical cancer. Therefore, HPV infection is one of major concern of cervical cancer diagnosis. HPV genotype-distribution data could provide useful information for establishing the appropriate vaccination program, and creating a diagnostic and treatment strategy for cervical cancer. In addition, data describing HPV prevalence by age can be used in early diagnoses. Previous studies focused on the relationship between HPV prevalence and age are few. Thus, the present study examined the correlation between HPV prevalence and age, as well as the relationship between HPV genotype-distribution and age.
The REBA HPV-ID ${ }^{\circledR}$ assay is a commercially utilized technique and has been used in other studies to clinically evaluate HPV genotyping analysis (Hu et al., 2011, Lee et al., 2011; Kim et al., 2012). In this study, REBA HPV-ID ${ }^{\circledR}$, which is based on the REBA (reverse blot hybridization assay), was performed to analyze HPV prevalence and genotype distribution with liquid-based cytological samples from women in East China (Western Shandong Province) and Korea (Gangwon Province). Samples were randomly selected to avoid selection bias.

In Chinese women, atypical squamous cells of undetermined significance (ASCUS) were the most common, observed in $29.6 \%$ of the cases (96 cases) (Table 1). In Korean women, normal and low-grade squamous intraepithelial lesions (LSIL) were the most common, observed in 35.8\% of the cases (191 cases). Samples from China were generally much more cases than those from Korea.

In terms of age, ASCUS was most common in women in their 40s and 50s, and high-grade squamous intraepithelial lesions (HSIL) were most common in women in their 40s, with prevalence rates of $8.6 \%, 8.3 \%$, and $7.4 \%$, respectively in Chinese women (Table 2). For Korean women, normal findings were most common in women in their 30s and 40s, and LSIL were most common in women in their 50s, with prevalence rates of $17.4 \%, 8.3 \%$, and $7.9 \%$, respectively.

High-risk HPV single infection is the most common type of infection in both Chinese and Korean women (Table 3). In Chinese women, HPV single infection rates were highest for women in their 40s, followed by women in their 50s, 30s, $<30$, and $>60(12.3 \%, 9.6 \%, 8.0 \%, 5.9 \%$ and $3.7 \%$, respectively). In Korean women, HPV single infection rates were highest for women $>60$, in their 50s, 30s, 40s, and $<30$ (53.3\%, 46.8\%, 44.8\%, 40.9\%, and 31.6\%, respectively). The highest non-infected age groups were Chinese women over $60(27.8 \%)$ and Korean women in their 40s (34.7\%). There were few low-risk HPV single-infections. Interestingly, there were no low-risk HPV multiple infections in China or Korea.

The most common HPV genotypes were 16, 53, 18, 58, and 33 in China and 16, 18, 58, 33, and 68 in Korea (Table 4). Across all age groups, HPV genotype 16 was the most common throughout China and Korea. HPV genotypes 53 and 
58 were most common in China, while HPV genotypes 58 and 68 were most common in Korea. HPV genotypes 16, 53, 58, and 68 have a close phylogenetic relationship. HPV is classified by DNA sequence similarity. Each species is subclassified into HPV genotypes. In general HPV genotypes have $>90 \%$ genetic homology (Bonnez, 1993), and HPV genotypes 16, 53, 58, and 68 all belong to the genus Alphapapillomavirus. HPV genotypes 16 and 58 are same species (de Villiers et al., 2004).

In summary, Women with severe dysplasia such as SCC (Squamous cell carcinoma) and HSIL (High-grade squamous intraepithelial lesion) groups were primarily in their 40s and 50s, whereas women with mild and moderate dysplasia (the ASCUS and LSIL groups) were primarily in their 30s and 40s. Women with HPV genotype 16 and 18 infections were primarily in their 40s.

Persistent HPV infections of at least 10 years most likely lead to cervical cancer (zur Hansen, 1994; Munoz et al., 2003). SCC and HSIL are associated with a high risk of cancer and are most commonly found in women in their 40s and 50s, whereas ASCUS and LSIL are associated with a low risk of cancer and are most commonly found in women in their 30s and 40s. Infection with HPV genotypes 16 and 18 are most commonly found in women in their 40s. These results suggest that HPV infection is associated with age group in Korean population.

\section{요 약}

자궁경부암은 전세계 여성에서 세 번째로 많이 발생하는 암이 다. 인유두종 바이러스(HPV) 감염이 자궁경부암 발병에 주요한 역 할을 한다. HPV 감염은 지리적 위치나 면역학적 상태, 성적 병력, 유전적 요인 등에 영향을 받는다. 예를 들어, $\mathrm{HPV}$ 감염률이 스페인 에서는 $1.5 \%$ 인 반면, 온두라스와 케냐에서는 $39 \%$ 에 육박한다. 그 러나 HPV 감염률과 나이와의 연관성에 대해서는 알려진 바가 적 다. 나이에 대한 $\mathrm{HPV}$ 감염률 분석은 어느 나이대가 자궁경부암에 고위험군인지를 알아낼 수 있다. 또한 특정 HPV 유전형과 나이 간 의 연관성을 입증할 수 있다. 게다가 백신을 주사하는 데에 최적의 나이대를 명확히 알 수 있을 것이다. 이 연구에서는 한국과 중국 여 성에서의 HPV 감염률과 유전형 분포를 나이에 따라 분석하였다. 한국과 중국 여성의 자궁 탈락 세포로 REBA HPV-ID ${ }^{\circledR}$ 검사법(YD
진단법, 용인, 대한민국)을 통해 HPV 유전형을 파악하였다. 편평세 포암과 고등급 병변의 환자군에서는 40 대와 50 대가 주를 이룬 반 면, 중간병변의 환자군에서는 30대와 40 대가 주를 이맀다. HPV 16,18 형 감염은 주로 40 대에 속했다. 이러한 결과는 지속적인 감 염이 자궁경부암을 일으킨다는 주장을 뒷받침한다.

\section{Acknowledgements: None}

Funding: None

Conflict of interest: None

\section{References}

1. Andersson E, Kärrberg C, Rådberg T, Blomqvist L, Zetterqvist BM, Ryd W, et al. Type-specific human papillomavirus E6/E7 mRNA detection by real-time PCR improves identification of cervical neoplasia. J Clin Microbiol. 2011,49(11):3794-3799. doi: 10.1128/JCM.00549-11.

2. Bonnez W. Taxonomy of the human papillomaviruses. Clin Infect Dis. 1993;17(6):1080.

3. Bosch FX, Manos MM, Muñoz N, Sherman M, Jansen AM, Peto J, et al. Prevalence of human papillomavirus in cervical cancer: a worldwide perspective. J Natl Cancer Inst. 1995,87:796-802.

4. Bosch FX, Muñoz N. The viral etiology of cervical cancer. Virus Res. 2002,89:183-190.

5. Bouvard V, Baan R, Straif K, Grosse Y, Secretan B, El GF, et al. A review of human carcinogens-part B: biological agents. Lancet Oncol. 2009;10:321-322.

6. Bruni L, Diaz M, Castellsagué X, Ferrer E, Bosch FX, de Sanjosé $\mathrm{S}$. Cervical human papillomavirus prevalence in 5 continents: meta-analysis of 1 million women with normal cytological findings. J Infect Dis. 2010;202:1789-1799.

7. de Villiers EM, Fauquet C, Broker TR, Bernard HU, zur Hausen Z. Classification of papillomaviruses. Virology. 2004,324:1727.

8. Hu SY, Hong Y, Zhao FH, Lewkowitz AK, Chen F, Zhang WH, et al. Prevalence of HPV infection and cervical intraepithelial neoplasia and attitudes towards HPV vaccination among Chinese women aged 1825 in Jiangsu province. Chin J Cancer Res. 2011,23(1):25-32.

9. Jemal A, Bray F, Center MM, Ferlay J, Ward E, Forman D. Global cancer statistics. CA Cancer J Clin. 2011,61:69-90.

10. Jennifer L. Human papillomavirus detection: Testing methodologies and their clinical utility in cervical cancer screening. $A d v$ Anat Pathol. 2013,20:158-167.

11. Kim SH, Lee DS, Kim Y, Kim GH, Park SJ, Choi YI, et al. Clinical evaluation of human papillomavirus DNA genotyping assay to diagnose women cervical cancer. J Exp Biomed Sci. 2012,18(2): 123-130.

12. Lee DS, Kim SH, Park SJ, Jin HW, Kim TU, Park KH, et al. Human papillomavirus prevalence in gangwon province using reverse blot hybridization assay. Korean J Pathol. 2011,45: 348-353.

13. Munoz N, Bosch X, de Sanjose S, Herrero R, Castellsague X, 
Shah KV, et al. Epidemiologic classification of human papillomavirus types associated with cervical cancer. $N$ Engl J Med. 2003,348:518-527.
14. zur Hausen Z. Molecular pathogenesis of cancer of the cervix and its causation by specific human papillomavirus types. Curr Top Microbiol Immunol. 1994,186:131-156. 